Sains Malaysiana 47(6)(2018): 1109-1115

http://dx.doi.org/10.17576/jsm-2018-4706-05

\title{
Potensi Afrodisiak Lunasia amara ke atas Tikus Jantan Teraruh Diabetes
}

(Aphrodisiac Potential of Lunasia amara on Diabetic-Induced Male Rats)

\author{
NOR-RAIDAH RAHMAT, AMIRA KAMALRUdin, SHAZRUL FAZRY \& MAHANEM MAT NOOR*
}

\section{ABSTRAK}

Diabetes melitus telah terbukti mengganggu penghasilan testosteron dan menyebabkan masalah libido dalam kalangan lelaki. Sehingga kini, tiada kajian mengenai potensi Lunasia amara dalam membaiki aktiviti seksual tikus jantan teraruh diabetes. Oleh itu, kajian ini dijalankan untuk mengenal pasti potensi afrodisiak L. amara ke atas tikus jantan teraruh diabetes. Empat kumpulan tikus teraruh diabetes masing-masing diberi perlakuan ekstrak L. amara (250 dan $500 \mathrm{mg} /$ $\mathrm{kg}$ berat tubuh), $500 \mathrm{mg} / \mathrm{kg}$ metformin dan air suling. Tikus kumpulan kawalan normal tanpa aruhan diabetes menerima perlakuan air suling. Perlakuan diberikan secara suap paksa selama 30 hari untuk melihat kesan L. amara ke atas status libido, aras testosteron serum, berat tubuh tikus, morfometri testis dan epididimis kauda serta aktiviti enzim antioksida testis tikus teraruh diabetes berbanding kawalan. Keputusan kajian menunjukkan berlaku penurunan libido, aras testosteron dan aktiviti khusus enzim antioksida (glutation peroksidase, katalase dan superoksida dismutase) testis tikus teraruh diabetes secara signifikan $(\mathrm{p}<0.05)$ pada kedua-dua dos tersebut berbanding kawalan normal. Sementara itu, perlakuan L. amara didapati tidak menjejaskan morfometri testis, epididimis kauda dan berat tubuh tikus yang menerima perlakuan L. amara berbanding kawalan normal. Kajian ini membuktikan bahawa ekstrak akuas batang L. amara pada dos 250 dan $500 \mathrm{mg} / \mathrm{kg}$ berat tubuh tidak berupaya memperbaiki aktiviti seksual tikus jantan teraruh diabetes.

Kata kunci: Afrodisiak; diabetes melitus; libido; Lunasia amara

ABSTRACT

Accumulating evidence shows that diabetes mellitus alters the production of testosterone and contributes to the reduction of libido in male. Formerly, no study has been conducted on the effect of Lunasia amara on sexual activity in diabeticinduced male rats. Therefore, present study looked into the aphrodisiac potential of L. amara on diabetic-induced male rats. Four groups of diabetic-induced male rats were given L. amara aqueous extract (250 and $500 \mathrm{mg} / \mathrm{kg}$ body weight), $500 \mathrm{mg} / \mathrm{kg}$ metformin and distilled water, respectively. A group of control rats was given distilled water. Treatments were given for 30 days to investigate the effect of L. amara aqueous extract on libido, serum testosterone level, body weight, morphometry of testis, cauda epididymis and antioxidant enzymes activity in diabetic-induced rats in comparison to control. The result showed diabetic-induced rats treated with both doses of $\mathrm{L}$. amara extract exhibit significant reduction $(\mathrm{p}<0.05)$ in libido, testosterone level, testis antioxidant enzymes activity (glutathione peroxidase, catalase and superoxide dismutase) compared to control. On the other hand, the administration of L. amara did not affect body weight, morphometry of testis and cauda epididymis of diabetic-induced rats compared to normal control. This findings suggested that $\mathrm{L}$. amara at doses 250 and $500 \mathrm{mg} / \mathrm{kg}$ body weight is incapable of improving sexual activity in diabetic-induced male rats.

Keywords: Aphrodisiac; diabetes mellitus; libido; Lunasia amara

\section{PENDAhUluan}

Diabetes melitus merupakan salah satu faktor yang menjejaskan aktiviti seksual lelaki. Giugliano et al. (2010) melaporkan bahawa penghidap diabetik adalah tiga kali ganda lebih berisiko untuk mengalami mati pucuk. Kajian terdahulu oleh Adewole et al. (2007) turut membuktikan bahawa tikus jantan teraruh diabetes mengalami kemerosotan libido yang signifikan berbanding kawalan. Tikus diaruh diabetes melalui suntikan streptozotocin (STZ). STZ yang disuntik secara intravena memasuki sel $\beta$ melalui GLUT2, merencat aktiviti akonitase serta terlibat dalam kerosakan DNA. Akibat daripada tindakan STZ ini, sel $\beta$ mengalami kemusnahan melalui apoptosis seterusnya menyebabkan peningkatan aras glukosa darah (Bathina et al. 2017). Hiperglisemia dan penurunan kepekatan insulin serum mengakibatkan penurunan aktiviti enzim antioksida yang penting seperti superoksida dismutase (SOD), glutation peroksidase (GPX) dan katalase (CAT) di dalam testis. Selain itu, tekanan oksidatif yang tinggi turut mengurangkan pembebasan nitrik oksida yang penting untuk fungsi korpus kavernosum. Kekurangan nitrik oksida ini akhirnya membawa kepada kegagalan ereksi (Tostes et al.2008). Diabetes juga dilaporkan menjejaskan penghasilan testosteron. Hal ini mungkin disebabkan oleh berkurangnya jumlah sel Leydig dan gangguan penghasilan androgen dalam pesakit diabetes lelaki (Al-Kuraishy \& Al- Gareeb 2016). Terdapat pelbagai tumbuhan herba yang digunakan dalam perubatan tradisional sebagai afrodisiak 
untuk mengatasi masalah libido rendah. Agen afrodisiak didefinisikan sebagai bahan yang meningkatkan keinginan dan keupayaan seksual (Sandroni 2001). Lunasia amara dilaporkan berupaya membaiki libido dan kualiti sperma tikus normal pada dos $60 \mathrm{mg} / \mathrm{kg}$ berat tubuh (Nor-Raidah \& Mahanem 2015). Melalui kajian proteomik dos 60 $\mathrm{mg} / \mathrm{kg}$ L. amara didapati meningkatkan pengekspresan pelbagai protein sperma yang terlibat dalam pergerakan sperma, metabolisme tenaga dan pengisyaratan sel yang menyumbang kepada peningkatan kesuburan tikus normal (Ja'far et al. 2017). Walau bagaimanapun, tiada kajian terdahulu yang mengkaji kesan L. amara ke atas libido tikus teraruh diabetes. Oleh itu, kajian ini dijalankan untuk mengenal pasti potensi $L$. amara sebagai agen afrodisiak dalam membaikpulih libido dan aktiviti seksual tikus teraruh diabetes.

\section{BAHAN DAN KAEDAH}

\section{PENYEDIAAN EKSTRAK AKUAS L. AMARA}

Batang L. amara diperoleh daripada Universiti Gadjah Mada, Indonesia. Spesies ini telah disahkan oleh Joko Santosa, ahli botani Universiti Gadjah Mada dengan nombor baucer spesimen 53/BFAR/020307. Ekstrak akuas batang L. amara disediakan berdasarkan kaedah Gonzales et al. (2006) dengan sedikit pengubahsuaian. Sebanyak $200 \mathrm{~g}$ batang L. amara dicampur dengan $1000 \mathrm{~mL}$ air suling dengan nisbah 1:5 dan dipanaskan pada suhu $80^{\circ} \mathrm{C}$ selama satu jam sebelum dituras menggunakan kertas Whatman 3.0. Hasil turasan disejukbekukan pada suhu $-20^{\circ} \mathrm{C}$ sebelum melalui kaedah pengeringan beku-kering (LabConco Corporation, Amerika Syarikat). Sampel bekukering disimpan pada suhu $4^{\circ} \mathrm{C}$. Serbuk batang L. amara ditimbang mengikut dos dan dilarutkan di dalam air suling sebelum digunakan.

\section{HAIWAN KAJIAN}

Sebanyak 25 ekor tikus Sprague-Dawley jantan (250-300 g) berumur 12 minggu diperoleh daripada Rumah Haiwan, Universiti Kebangsaan Malaysia (UKM). Minuman dan pelet makanan (Barastock Rat and Mouse Pelleted Feed, Australia) diberikan secara ad libitum setiap hari. Tikus menerima cahaya selama 12 jam sehari pada suhu 27 $32^{\circ} \mathrm{C}$. Tikus yang telah dipuasakan semalaman diaruh diabetes dengan suntikan intravena $55 \mathrm{mg} / \mathrm{kg}$ berat tubuh streptozotocin (STZ) yang telah dilarutkan dalam larutan penimbal natrium sitrat ( $\mathrm{pH} 4.5)$. Aras glukosa darah tikus puasa diukur menggunakan glukometer (Accucheck Performa, Roche) selepas lima hari suntikan STZ. Tikus yang mempunyai aras glukosa melebihi $13 \mathrm{mmol} / \mathrm{L}$ dikategorikan sebagai diabetes dan digunakan di dalam kajian. Sejumlah 20 ekor tikus teraruh diabetes dibahagikan kepada empat kumpulan iaitu kumpulan perlakuan ekstrak akuas $L$. amara dengan dos $250 \mathrm{mg} / \mathrm{kg}(n=5)$ dan dos $500 \mathrm{mg} / \mathrm{kg}(n=5)$, kumpulan kawalan positif $(n=5)$ yang menerima $500 \mathrm{mg} / \mathrm{kg}$ berat tubuh metformin dan kumpulan kawalan negatif $(n=5)$ yang menerima air suling. Kumpulan kelima ialah kumpulan kawalan normal $(n=5)$. Tikus diberikan perlakuan selama 30 hari secara suap paksa. Kajian ini mendapat kelulusan daripada Jawatankuasa Etika Haiwan Universiti Kebangsaan Malaysia (Nombor kelulusan UKMAEC: FST/2013/MAHANEM/31-JAN./492FEB.-2013-FEB.-2015).

\section{UJIAN LIBIDO}

Tikus betina diaruh supaya berada dalam keadaan bersedia mengawan dengan diberi suntikan estradiol benzoat dan progesteron secara subkutan di bahagian dorsal tikus. Sebanyak $20 \mu \mathrm{g}$ estradiol benzoat disuntik 48 jam sebelum suntikan $1 \mathrm{mg}$ progesteron dilakukan. Selepas 4 jam suntikan progesteron dilakukan, tikus betina disahkan bersedia untuk mengawan dengan menggunakan teknik calitan faraj (Agmo 1997). Ujian libido dilakukan dengan membiarkan tikus jantan selama 5 min di dalam sangkar gelap bersaiz $60 \times 40 \times 20 \mathrm{~cm}$ untuk penyesuaian diri sebelum tikus betina yang berada dalam fasa estrus dimasukkan (nisbah 1:1). Jumlah pemanjatan tikus jantan ke atas tikus betina dicatatkan dalam tempoh masa $10 \mathrm{~min}$ pemerhatian.

\section{ANALISIS ARAS TESTOSTERON}

Selepas tikus dikorbankan, $4 \mathrm{~mL}$ darah diambil daripada jantung tikus dengan menggunakan jarum picagari pada jam 10 pagi. Darah kemudiannya diempar dengan kelajuan $2500 \mathrm{rpm}$ selama $15 \mathrm{~min}$. Serum yang berada di lapisan atas diasingkan dan disimpan pada suhu $-20^{\circ} \mathrm{C}$ sehingga digunakan. Aras testosteron ditentukan dengan menggunakan kit diagnostik Testosterone EIA (Cayman Chemical, Michigan, USA) berdasarkan kaedah Maclouf et al. (1987) dan Pradelles et al. (1985).

\section{ANALISIS BERAT TUBUH TIKUS SERTA MORFOMETRI TESTIS DAN EPIDIDIMIS KAUDA}

Testis dan epididimis kauda ditimbang menggunakan penimbang digital sebelum dilakukan pengukuran panjang dan lebar dengan menggunakan angkup Vernier digital.

\section{PENGASAIAN ENZIM ANTIOKSIDA TESTIS}

Hemogenat testis disediakan mengikut kaedah Choi et al. (2007). Sebanyak $200 \mathrm{mg}$ hemogenat testis dicampur ke dalam $1 \mathrm{~mL}$ PBS (pH7.4) dan diempar selama $15 \mathrm{~min}$ pada suhu $4^{\circ} \mathrm{C}$ dengan kelajuan $10,000 \times$ g. Supernatan diasingkan untuk analisis aktiviti spesifik enzim antioksida testis iaitu superoksida dismutase (SOD), glutation peroksidase (GPX) dan katalase (CAT).

Jumlah aktiviti spesifik enzim superoksida dismutase ditentukan berdasarkan kit pengasaian Superoksida Dismutase (Cayman Chemical, Michigan, USA). Sebanyak $200 \mu \mathrm{L}$ pengesan radikal dipipetkan ke dalam telaga mikroplat. Kemudian, $10 \mu \mathrm{L}$ SOD piawai $(0,0.025,0.05$, $0.1,0.15,0.2,0.25 \mathrm{U} / \mathrm{mL}$ ) dan sampel dipipetkan ke dalam telaga masing-masing yang berisi pengesan radikal. Tindak 
balas reaksi dimulakan dengan menambah $20 \mu \mathrm{L}$ Xanthine Oxidase ke dalam semua telaga yang digunakan. Nilai penyerapan asai diukur pada jarak gelombang 440-460 nm (Bio-Rad Model 680 Microplate Reader, Jepun). Satu unit SOD ditakrifkan sebagai jumlah enzim yang diperlukan untuk 50\% dismutasi radikal superoksida (U/mL).

Jumlah aktiviti spesifik enzim glutation peroksidase (GPX) ditentukan berdasarkan kit pengasaian Glutathione Peroxidase (Cayman Chemical, Michigan, USA) mengikut kaedah Paglia dan Valentine (1967). Asai dijalankan menggunakan mikroplat dan kawalan kosong disediakan dengan mencampurkan $120 \mu \mathrm{L}$ penimbal asai dan $50 \mu \mathrm{L}$ campuran ko-substrat ke dalam telaga. Sebanyak $20 \mu \mathrm{L}$ GPX piawai (kawalan positif) dan sampel dimasukkan ke dalam telaga masing-masing yang telah sedia ada $100 \mu \mathrm{L}$ penimbal asai dan $50 \mu \mathrm{L}$ campuran ko-substrat. Tindak balas reaksi dimulakan dengan menambah $20 \mu \mathrm{L}$ Cumene hidroperoksida ke dalam semua telaga. Bacaan diambil pada jarak penyerapan gelombang $340 \mathrm{~nm}$ (Bio-Rad Model 680 Microplate Reader, Jepun).

Kit pengasaian Katalase (Cayman Chemical, Michigan, USA) menggunakan fungsi peroksidatif katalase untuk menentukan aktiviti enzim. Sebanyak $100 \mu \mathrm{L}$ penimbal asai dan $30 \mu \mathrm{L}$ metanol dipipetkan ke dalam telaga mikroplat. Kemudian, formaldehid piawai (kepekatan 0, 5, 15, 30, 45, 60 dan $75 \mu \mathrm{M}$ ), katalase piawai dan sampel masing-masing sebanyak $20 \mu \mathrm{L}$ dipipetkan ke dalam telaga mikroplat yang telah sedia penimbal asai dan metanol. Sebanyak $20 \mu \mathrm{L}$ hidrogen peroksida ditambah kepada semua telaga untuk memulakan tindak balas diikuti oleh $30 \mu \mathrm{L}$ katalase purpald (kromagen) selepas $20 \mathrm{~min}$ untuk menghentikan tindak balas. Selepas 10 minit, $10 \mu \mathrm{L}$ katalase potassium periodate ditambah ke dalam setiap telaga dan bacaan penyerapan diukur pada jarak gelombang 540 nm (Bio-Rad Model 680 Microplate Reader, Jepun). Satu unit CAT ditakrifkan sebagai jumlah enzim yang akan menyebabkan pembentukan $1.0 \mathrm{nmol}$ formaldehid per minit pada suhu $25^{\circ} \mathrm{C}$.

\section{ANALISIS STATISTIK}

Analisis statistik dijalankan menggunakan perisian SPSS versi 22. Data dianalisis dengan menggunakan ujian t. Perbezaan data antara kumpulan kawalan dan perlakuan dianggap signifikan apabila nilai $p<0.05$.

\section{KEPUTUSAN DAN PERBINCANGAN}

\section{AKTIVITI LIBIDO}

Kajian ini merupakan kajian saintifik pertama dalam mengkaji keupayaan ekstrak akuas batang L. amara sebagai agen afrodisiak pada tikus jantan teraruh diabetes. Walaupun L. amara pada dos rendah $(60 \mathrm{mg} / \mathrm{kg}$ berat tubuh) berupaya membaiki libido dan kualiti sperma tikus normal (Nor-Raidah \& Mahanem 2015), namun dos ini tidak berjaya menurunkan aras glukosa tikus teraruh diabetes. Keputusan daripada kajian antihiperglisemia $L$. amara, dos tinggi iaitu 250 dan $500 \mathrm{mg} / \mathrm{kg}$ L. amara dipilih untuk kajian afrodisiak kerana berupaya menurunkan aras glukosa darah tikus teraruh diabetes secara signifikan (NorRaidah 2016). Jadual 1 menunjukkan kesan ekstrak akuas batang L. amara ke atas kelakuan seksual tikus jantan teraruh diabetes berbanding tikus kawalan. Tikus teraruh diabetes yang diberi dos perlakuan $500 \mathrm{mg} / \mathrm{kg}$ berat tubuh L. amara tidak menunjukkan sebarang aktiviti pemanjatan ke atas tikus betina manakala tikus teraruh diabetes yang diberi dos perlakuan $250 \mathrm{mg} / \mathrm{kg}$ berat tubuh L. amara mencatatkan purata bilangan kekerapan pemanjatan yang rendah $(p<0.05)$ iaitu sebanyak $0.5 \pm 0.29$ berbanding tikus kawalan normal $(2.75 \pm 0.48)$. Penurunan libido tikus teraruh diabetes ini berpunca daripada masalah kerintangan insulin. Hal ini mengakibatkan gangguan pada paksi hipotalamik-pituitari-gonadal yang seterusnya membawa kepada masalah penghasilan atau fungsi hormon testosteron (Rehman et al. 2001). Walaupun perlakuan $L$. amara berupaya meningkatkan libido pada tikus normal (Nor-Raidah \& Mahanem 2015), tetapi herba ini didapati tidak membaiki masalah libido tikus teraruh diabetes apabila dos ditingkatkan. Peningkatan dos perlakuan $L$. amara terhadap tikus teraruh diabetes sebaliknya dilihat menyumbang kepada penurunan libido pada tikus teraruh diabetes.

\section{ARAS TESTOSTERON}

Aras testosteron ditentukan bagi mengkaji korelasi antara aras testosteron dengan kelakuan seksual tikus teraruh diabetes yang diberi perlakuan L. amara . Rajah 1 menunjukkan perbandingan aras testosteron tikus teraruh diabetes yang menerima perlakuan L. amara berbanding tikus kawalan. Keputusan kajian mendapati bahawa

JADUAL 1. Kesan perlakuan L. amara ke atas libido tikus teraruh diabetes berbanding kumpulan kawalan (a $p<0.05$ berbanding kawalan normal, ${ }^{\mathrm{b}} p<0.05$ berbanding kawalan negatif $\&^{\mathrm{c}} p<0.05$ berbanding kawalan positif)

\begin{tabular}{cc}
\hline Kumpulan & Purata kekerapan pemanjatan tikus jantan (10 min) \\
\hline Kawalan normal & $3.00 \pm 0.48$ \\
Kawalan negatif (Diabetes) & $\mathrm{TA}^{\mathrm{a}}$ \\
Kawalan positif (Diabetes + metformin) & $1.00 \pm 0.41^{\mathrm{a}, \mathrm{b}}$ \\
Diabetes + 250 mg/kg L. amara & $0 \pm 0.29^{\mathrm{a}}$ \\
Diabetes $+500 \mathrm{mg} / \mathrm{kg}$ L. amara & $\mathrm{TA}^{\mathrm{a}, \mathrm{c}}$ \\
\hline
\end{tabular}

$\mathrm{TA}=$ Tiada aktiviti 


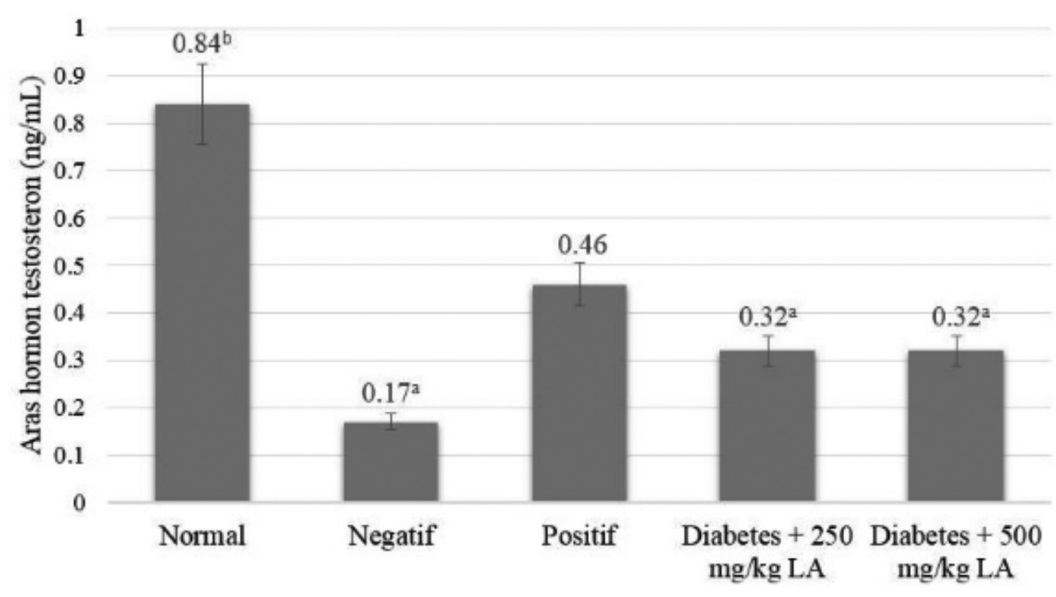

RAJAH 1. Kesan perlakuan L. amara ke atas aras testosteron tikus teraruh diabetes berbanding kumpulan kawalan ( ${ }^{\mathrm{a}} p<0.05$ berbanding kawalan normal, ${ }^{\mathrm{b}} p<0.05$ berbanding kawalan negatif). (LA = L. amara $)$

aruhan STZ telah menurunkan aras testosteron secara signifikan $(p<0.05)$ sebanyak $80 \%$ iaitu $0.17 \pm 0.02 \mathrm{ng} /$ $\mathrm{mL}$ berbanding tikus kawalan normal iaitu $0.84 \pm 0.09 \mathrm{ng} /$ $\mathrm{mL}$. Perlakuan L. amara terhadap tikus teraruh diabetes berjaya meningkatkan aras testosteron pada kedua-dua dos perlakuan iaitu masing-masing $0.32 \pm 0.05 \mathrm{ng} / \mathrm{mL}$ (dos 250 $\mathrm{mg} / \mathrm{kg}$ ) dan $0.32 \pm 0.04 \mathrm{ng} / \mathrm{mL}(\mathrm{dos} 500 \mathrm{mg} / \mathrm{kg})$ berbanding tikus kawalan negatif $(0.17 \pm 0.07 \mathrm{ng} / \mathrm{mL})$. Menurut Subash-Babu et al. (2014) aruhan STZ menyebabkan tekanan oksidatif pada organ testis dengan peningkatan aras asid reaktif tiobarbiturik (TBARS), hidroperoksida dan spesies oksigen reaktif (ROS) secara signifikan berbanding tikus normal. Keadaan ini mengakibatkan perubahan struktur dan fungsi sel Leydig yang menyebabkan gangguan dalam penghasilan hormon testosteron (Zhao et al. 2016). Walaupun perlakuan L. amara meningkatkan penghasilan hormon testosteron tikus teraruh diabetes, tetapi peningkatan tersebut adalah tidak signifikan jika dibandingkan dengan kawalan negatif (Rajah 1).

\section{BERAT TUBUH TIKUS SERTA MORFOMETRI TESTIS DAN EPIDIDIMIS KAUDA}

Perubahan aras testosteron yang ketara pada tikus teraruh diabetes berkemungkinan mengganggu perkembangan organ reproduktif seperti testis dan epididimis. Oleh yang demikian, analisis perubahan berat dan morfometri testis serta epididimis kauda tikus teraruh diabetes dilakukan. Perubahan berat tubuh dan morfometri organ testis pada tikus teraruh diabetes yang diberi perlakuan L. amara ditunjukkan dalam Jadual 2. Aruhan STZ telah menurunkan berat tubuh tikus secara signifikan $(p<0.05)$ sebanyak $28.55 \%$ iaitu $212.00 \pm 14.39 \mathrm{~g}$ berbanding kawalan normal iaitu $296.70 \pm 12.67 \mathrm{~g}$. Berat tubuh tikus teraruh diabetes yang diberi perlakuan L. amara turut menurun iaitu 196.15 $\pm 24.03 \mathrm{~g}$ (perlakuan $250 \mathrm{mg} / \mathrm{kg}$ L. amara) dan $203.15 \pm$ $8.65 \mathrm{~g}$ (perlakuan $500 \mathrm{mg} / \mathrm{kg}$ L. amara) berbanding tikus kawalan normal. Pemberian dos perlakuan 250 dan 500 $\mathrm{mg} / \mathrm{kg}$ pada tikus teraruh diabetes masing-masing telah meningkatkan berat relatif testis secara tidak signifikan ( $p>0.05$ ) berbanding kesemua tikus kumpulan kawalan. Manakala, panjang testis tikus teraruh diabetes yang diberi dos perlakuan $250 \mathrm{mg} / \mathrm{kg}$ telah menunjukkan peningkatan berbanding kumpulan perlakuan $500 \mathrm{mg}$ / kg dan kesemua kumpulan kawalan. Hasil cerapan lebar testis tikus teraruh diabetes pada ke dua-dua kumpulan yang diberi dos perlakuan L. amara tidak menunjukkan perbezaan bacaan yang signifikan $(p>0.05)$ berbanding tikus kawalan negatif.

Perbandingan purata berat relatif dan morfometri epididimis kauda tikus kajian ditunjukkan pada Jadual 3. Berat relatif epididimis kauda tikus teraruh diabetes dengan perlakuan 250 dan $500 \mathrm{mg} / \mathrm{kg}$ menunjukkan peningkatan

JADUAL 2. Berat relatif per $100 \mathrm{~g}$ BT serta panjang dan lebar testis tikus teraruh diabetes dengan perlakuan L. amara berbanding kumpulan kawalan ( ${ }^{*} p<0.05$ berbanding kawalan normal)

\begin{tabular}{lcccc}
\hline Kumpulan & Berat tubuh $(\mathrm{g})$ & $\begin{array}{c}\text { Berat relatif testis } \\
\text { per 100 g BT }(\mathrm{g})\end{array}$ & Panjang $(\mathrm{mm})$ & Lebar $(\mathrm{mm})$ \\
\hline Kawalan normal & $296.70 \pm 12.67$ & $0.53 \pm 0.03$ & $19.04 \pm 0.08$ & $11.78 \pm 0.38$ \\
Kawalan negatif (Diabetes) & $212.00 \pm 14.39^{*}$ & $0.51 \pm 0.09$ & $18.31 \pm 0.51$ & $10.37 \pm 0.43$ \\
Kawalan positif (Diabetes + metformin) & $191.10 \pm 15.05^{*}$ & $0.49 \pm 0.05$ & $19.06 \pm 0.64$ & $9.95 \pm 0.46^{*}$ \\
Diabetes + 250 mg/kg LA & $196.15 \pm 24.03^{*}$ & $0.59 \pm 0.03$ & $19.15 \pm 0.76$ & $10.21 \pm 0.41$ \\
Diabetes + 500 mg/kg LA & $205.13 \pm 8.65^{*}$ & $0.54 \pm 0.04$ & $18.77 \pm 0.46$ & $10.23 \pm 0.32$ \\
\hline
\end{tabular}

\footnotetext{
$\mathrm{BT}=$ Berat tubuh; $\mathrm{LA}=$ L. amara
} 
JADUAL 3. Berat relatif per $100 \mathrm{~g}$ BT serta panjang dan lebar epididimis kauda tikus teraruh diabetes dengan perlakuan L. amara berbanding tikus kawalan $\left({ }^{*} p<0.05\right.$ berbanding kawalan normal)

\begin{tabular}{lcc}
\hline Kumpulan & $\begin{array}{c}\text { Berat relatif epididimis kauda } \\
\text { per 100g BT }(\mathrm{g})\end{array}$ & Panjang $(\mathrm{mm})$ \\
\hline Kawalan normal & $0.067 \pm 0.004$ & $9.90 \pm 0.39$ \\
Kawalan negatif (Diabetes) & $0.051 \pm 0.0015$ & $8.82 \pm 0.81$ \\
Kawalan positif (Diabetes + metformin) & $0.047 \pm 0.0033^{*}$ & $8.24 \pm 0.27$ \\
Diabetes + 250 mg/kg LA & $0.062 \pm 0.003$ & $8.00 \pm 0.71$ \\
Diabetes + 500 mg/kg LA & $0.054 \pm 0.003$ & $8.41 \pm 0.35 \pm 0.27^{*}$ \\
\hline
\end{tabular}

$\mathrm{LA}=$ L. amara

berat yang tidak signifikan $(p>0.05)$ berbanding tikus kawalan negatif dan positif. Nilai bacaan panjang dan lebar epididimis kauda tikus teraruh diabetes perlakuan L.amara pada ke dua-dua dos menunjukkan perbezaan yang tidak signifikan $(p>0.05)$ berbanding tikus kumpulan kawalan. Penurunan berat badan tikus teraruh diabetes berbanding tikus normal turut dilaporkan oleh Chaudhry et al. (2016) selepas suntikan STZ diberikan. Secara keseluruhannya, aruhan diabetes hanya menurunkan berat tubuh tikus secara signifikan tetapi tidak menjejaskan purata pengukuran berat relatif, panjang dan lebar testis serta epididimis kauda tikus diabetes berbanding kawalan normal. Perlakuan $L$. amara didapati tidak membantu meningkatkan berat tubuh tikus diabetes kepada normal. Keputusan kajian ini turut mendapati bahawa ekstrak akuas batang L. amara pada dos 250 dan $500 \mathrm{mg} / \mathrm{kg}$ masing-masing tidak memberikan perubahan ketara pada berat dan morfometri organ reproduktif tikus jantan teraruh diabetes. Ciri fizikal seperti morfologi dan anatomi ke dua-dua organ ini adalah normal sebagaimana kawalan normal. Oleh itu pengambilan L. amara sebagai ubatan didapati tidak mengganggu perkembangan ke dua-dua organ pembiakan jantan ini.

\section{AKTIVITI ENZIM ANTIOKSIDA TESTIS}

Aruhan STZ menurunkan aras aktiviti spesifik enzim GPX, CAT dan SOD testis tikus kawalan negatif secara tidak signifikan $(p>0.05)$ berbanding tikus kawalan normal (Jadual 4). Diabetes sering dikaitkan dengan gangguan terhadap sistem pertahanan antioksida dan peningkatan radikal bebas (Maritim et al. 2003). Tekanan oksidatif berlaku apabila spesies oksigen reaktif (ROS) mendorong pengoksidaan $\beta$ asid lemak yang akhirnya menyebabkan berlaku pengoksidaan lipid. Pengoksidaan lipid yang tinggi boleh merosakkan fungsi membran dengan menurunkan kebendaliran membran dan mengubah aktiviti membran berikat enzim reseptor. Peningkatan Ros di dalam mitokondria sperma juga disumbangkan oleh oksidatif fosforilasi dan oksidasi auto dalam keadaan hiperglisemia (Giacco \& Brownlee 2010). Aras aktiviti spesifik enzim GPx tikus teraruh diabetes perlakuan 250 dan $500 \mathrm{mg} / \mathrm{kg}$ menunjukkan penurunan signifikan $(p<0.05)$ iaitu masingmasing sebanyak $46.37 \%(22.18 \pm 0.12 \mathrm{U} / \mathrm{mg})$ dan $57 \%$ $(17.76 \pm 0.44 \mathrm{U} / \mathrm{mg})$ berbanding kawalan normal (53.64 $\pm 6.77 \mathrm{U} / \mathrm{mg}$ ). Aras aktiviti spesifik enzim CAT pada tikus teraruh diabetes kedua-dua dos perlakuan L. amara turut berlaku penurunan signifikan $(p<0.05)$ iaitu sebanyak $48.77 \%(1.25 \pm 0.41 \mathrm{U} / \mathrm{mg})$ pada dos perlakuan $250 \mathrm{mg} /$ $\mathrm{kg}$ dan $45.9 \%(1.32 \pm 0.23 \mathrm{U} / \mathrm{mg})$ pada dos perlakuan $500 \mathrm{mg} / \mathrm{kg}$ berbanding kawalan normal $(2.54 \pm 0.20 \mathrm{U} /$ $\mathrm{mg}$ ). Perlakuan $250 \mathrm{mg} / \mathrm{kg} \mathrm{L}$. amara pada tikus teraruh diabetes juga menurunkan aras aktiviti spesifik enzim SOD $(p>0.05)$ sebanyak $36 \%(14.87 \pm 1.05 \mathrm{U} / \mathrm{mg})$ manakala dos perlakuan $500 \mathrm{mg} / \mathrm{kg}$ menurun $(p<0.05)$ sebanyak $49.79 \%(11.68 \pm 2.47 \mathrm{U} / \mathrm{mg})$ berbanding kawalan normal $(41.36 \pm 7.65 \mathrm{U} / \mathrm{mg})$.

Secara umumnya, berlaku penurunan aktiviti ketigatiga enzim antioksida pada serum kumpulan tikus teraruh diabetes berbanding kawalan normal. Ini mungkin disebabkan oleh peningkatan tekanan oksidatif yang menindas sistem pertahanan antioksida di dalam sel testis. Keadaan hiperglisemia meningkatkan produk akhir proses glikasi lanjut (AGE) di dalam tikus teraruh diabetes (Vlassara \& Striker 2013). Zhao et al. (2016) mendapati pembentukan produk AGE telah meningkatkan tekanan oksidatif di dalam sel Leydig. Keadaan ini seterusnya menjejaskan struktur dan fungsi sel Leydig yang akhirnya merencatkan penghasilan testosteron yang penting untuk libido. Keputusan kajian aras enzim antioksida testis ini selari dengan keputusan kajian aras testosteron yang turut merosot pada semua kumpulan tikus teraruh diabetes berbanding kumpulan normal. Gangguan pada fungsi sel testis ini boleh mengakibatkan libido dan kualiti sperma yang dihasilkan oleh pesakit diabetes menurun (Amaral et al. 2008). Perlakuan L. amara pada dos 250 dan $500 \mathrm{mg} / \mathrm{kg}$ masing-masing didapati tidak mampu mengatasi masalah libido yang merupakan kesan sampingan akibat diabetes.

Kandungan bioaktif tumbuhan memainkan peranan penting dalam mengaruh pembaikan libido jantan. Kandungan alkaloid $L$. amara yang tinggi seperti quinoline, 3-dimethylallyl-2-quinolone, furokuinolin, 2-arilkuinolin dan 4-kuinolon (Sharma et al. 2010; Zubair et al. 2016) didapati tidak berkesan dalam membaiki libido tikus diabetes walaupun berjaya menurunkan aras glukosa darah. L. amara juga dikenal pasti tidak berupaya meningkatkan aktiviti enzim antioksida (SOD, CAT dan GPx) untuk menurunkan tekanan oksidatif di dalam testis tikus diabetes. Pemulihan pada sistem endokrin dan sistem pertahanan antioksida adalah penting untuk kesihatan seksual. 
JADUAL 4. Kesan perlakuan L. amara ke atas aktiviti spesifik enzim glutation peroksidase (GPx), katalase (CAT), dan superoksida dismutase (SOD) tikus teraruh diabetes berbanding kumpulan kawalan. ( $p<0.05$ berbanding kawalan normal)

\begin{tabular}{lccc}
\hline & & Aktiviti spesifik enzim (U/mg) \\
\cline { 2 - 4 } Kumpulan & $\begin{array}{c}\text { Glutation peroksidase } \\
(\mathrm{GPx})\end{array}$ & $\begin{array}{c}\text { Katalase } \\
(\mathrm{CAT})\end{array}$ & $\begin{array}{c}\text { Superoksida dismutase } \\
(\mathrm{SOD})\end{array}$ \\
\hline Kawalan normal & $53.64 \pm 6.77$ & $2.54 \pm 0.2$ & $25.85 \pm 4.28$ \\
Kawalan negatif (Diabetes) & $41.36 \pm 7.65$ & $2.44 \pm 0.17$ & $23.26 \pm 3.58$ \\
Kawalan positif (Diabetes + metformin) & $37.43 \pm 2.91$ & $1.25 \pm 0.41 *$ & $25.65 \pm 4.15$ \\
Diabetes + $250 \mathrm{mg} / \mathrm{kg}$ L. amara & $22.18 \pm 0.12 *$ & $1.32 \pm 0.23 *$ & $14.87 \pm 1.05$ \\
Diabetes + 500 mg/kg L. amara & $17.76 \pm 0.44 *$ & & $11.68 \pm 2.47 *$ \\
\hline
\end{tabular}

\section{KESIMPULAN}

Secara ringkas dapat disimpulkan bahawa ekstrak akuas batang L. amara menunjukkan kesan antihiperglisemia pada dos tinggi (250 dan $500 \mathrm{mg} / \mathrm{kg}$ berat tubuh) tetapi merencatkan libido tikus jantan teraruh diabetes. Sebaliknya pada dos rendah $(60 \mathrm{mg} / \mathrm{kg})$ L. amara berupaya meningkatkan libido tikus jantan normal, namun tidak membantu menurunkan aras glukosa darah tikus teraruh diabetes secara signifikan. Tidak seperti herba lain seperti Gynura procumbens yang menunjukkan kesan pro-libido di samping menurunkan aras glukosa darah tikus teraruh diabetes pada dos rendah $(50 \mathrm{mg} / \mathrm{kg}$ berat tubuh) berbanding kawalan normal (Mahanem \& Nani Rahayu 2012), L. amara didapati tidak berupaya merawat kedua-dua masalah tersebut pada masa yang sama. Oleh itu, pemilihan dos memainkan peranan penting untuk mengatasi kedua-dua masalah libido dan hiperglisemia tikus teraruh diabetes.

\section{PENGHARGAAN}

Penulis berterima kasih kepada Fakulti Sains dan Teknologi, Universiti Kebangsaan Malaysia atas kemudahan penyelidikan yang disediakan serta geran penyelidikan STGL-006-2007.

\section{RUJUKAN}

Adewole, S.O., Caxton-Martins, E.A., Salako, A.A., Dohertu, O.W. \& Naicker,T. 2007. Effects of oxidative stress induced by streptozotocin on the morphology and trace minerals of the testes of diabetic Wistar rats. Pharmacologyonline 2: 478-497.

Agmo, A. 1997. Male rat sexual behavior. Brain Research Protocol 1: 203-209.

Al-Kuraishy, H.M. \& Al-Gareeb, A.I. 2016. Erectile dysfunction and low sex drive in men with type 2 DM: The potential role of diabetic pharmacotherapy. Journal of Clinical and Diagnostic Research 10(12): FC21-FC26.

Amaral, S., Oliveira, P.J. \& Ramalho-Santos, J. 2008. Diabetes and the impairment of reproductive function: Possible role of mitochondria and reactive oxygen. Current Diabetes Reviews 4(1): 46-54.

Bathina, S., Srinivas, N. \& Das, U.N. 2017. Streptozotocin produces oxidative stress, inflammation and decreases BDNF concentrations to induce apoptosis of RIN5F cells and type 2 diabetes mellitus in Wistar rats. Biochemical and Biophysical Research Communications 486(2): 406-413.

Chaudhry, Z.R., Naseer, A., Chaudhry, S.R., Chaudhry, E.R. \& Chaudhry, F.R. 2016. Comparison of extracts of Syzygium aromaticum on the weight of STZ induced diabetic rats. Journal of Islamic International Medical College 11(1): 24-28.

Choi, J.S., Kim, I.W., Hwang, S.Y., Shin, B.J. \& Kim, S.K. 2007. Effect of 2,3,7,8 tetrachlorodibenzo-p-dioxin on testicular spermatogenesis-related panels and serum sex hormone levels in rats. BJU International 101: 250-255.

Giacco, F. \& Brownlee, M. 2010. Oxidative stress and diabetic complications. Circulation Research 107: 1058-1070.

Giugliano, F., Maiorino, M., Bellastella, G., Gicchino, M., Giugliano, D. \& Esposito, K. 2010. Determinants of erectile dysfunction in type 2 diabetes. International Journal of Impotence Research 22: 204-209.

Gonzales, C., Rubio, J., Gasco, M., Nieto, J., Yucra, S. \& Gonzales, G.F. 2006. Effect of short-term and long-term treatments with three ecotypes of Lepidium meyenii (MACA) on spermatogenesis in rats. Journal of Ethnopharmacology 103: 448-454.

Ja'far, M.L., Amira, K. \& Mahanem, M.N. 2017. Effects of Lunasia amara blanco (Sanrego) on male fertility: A preliminary study on sperm proteomic analysis. Journal of Applied Pharmaceutical Science 7(8): 85-91.

Maclouf, J., Grassi, J. \& Pradelles, P. 1987. Development of enzyme-immunoassay techniques for the measurement of eicosanoids. Dlm Prostaglandin and Lipid Metabolism in Radiation Injury disunting oleh Walden, T.L., Jr. \& Hughes, H.N. Rockville: Plenum Press. hlm. 355-364.

Mahanem, M.N. \& Nani Rahayu, M.R. 2012. Kesan antihiperglisemia ekstrak metanol Gynura procumbens terhadap kesuburan dan libido tikus jantan teraruh diabetes. Sains Malaysiana 41(12): 1549-1556.

Maritim, A.C., Sanders, R.A. \& Watkins, J.B. 2003. Diabetes, oxidative stress, and antioxidants: A review. Journal of Biochemical and Molecular Toxicology 17(1): 24-38.

Nor-Raidah, R. 2016. Kesan ekstrak akuas batang Lunasia amara terhadap libido dan kesuburan tikus jantan teraruh diabetes. Tesis Sarjana Sains, Fakulti Sains dan Teknologi, Universiti Kebangsaan Malaysia, Malaysia (tidak diterbitkan).

Nor-Raidah, R. \& Mahanem, M.N. 2015. Enhancement of fertility and libido in male Sprague Dawley rats following the administration of aqueous extract of Lunasia amara. Malaysian Applied Biology 44(1): 125-131.

Paglia,D.E. \& Valentine, W.N. 1967. Studies on the quantitative and quantitative and qualitative characterization of 
erythrocyte glutathione peroxidase. Journal of Laboratory and Clinical Medicine 70: 158-169.

Pradelles, P., Grassi, J. \& Maclouf, J.A. 1985. Enzyme immunoassays of eicosanoids using acetylcholine esterase as label: An alternative to radioimmunoassay. Analytical Chemistry 57: 1170-1173.

Rehman, K., Beshay, E. \& Carrier, S. 2001 . Diabetes and male sexual function. Journal of Sexual Reproductive Medicine 1: 29-33.

Sandroni, P. 2001. Aphrodisiacs past and present: A historical review. Clinical Autonomic Research 1: 303-307.

Sharma, B., Salunke, R., Balomajumder, C., Daniel, S. \& Roy, P. 2010. Anti-diabetic potential of alkaloid rich fraction from Capparis decidua on diabetic mice. Journal of Ethnopharmacology 127: 457-462.

Subash-Babu, P., Alshatwil, A.A. \& Ignacimuthu, S. 2014. Beneficial antioxidative and antiperoxidative effect of cinnamaldehyde protect streptozotocin-induced pancreatic $\beta$-cells damage in Wistar rats. Biomolecules \& Therapeutics 22(1): 47-54.

Tostes, R.C., Carneiro, F.S., Lee, A.J., Giachini, F.R.C., Leite, R., Osawa Y. \& Webb, R.C. 2008. Cigarette smoking and erectile dysfunction: Focus on NO bioavailability and ROS generation. The Journal of Sexual Medicine 5(6): 1284-1295.

Vlassara, H. \& Striker, E.G. 2013. Advanced glycation end products in diabetes and diabetic complications. Endocrinology and Metabolism Clinics 42(4): 697-719.
Zhao, Y.T., Qi, Y.W., Hu, C.Y., Chen, S.H. \& Liu, Y. 2016. Advanced glycation end products inhibit testosterone secretion by rat Leydig cells by inducing oxidative stress and endoplasmic reticulum stress. International Journal of Molecular Medicine 38: 659-665.

Zubair, M.S., Anam, S. \& Lallo, S. 2016. Cytotoxic activity and phytochemical standardization of Lunasia amara blanco wood extract. Asian Pacific Journal of Tropical Biomedicine 6(11): 962-966.

Pusat Pengajian Biosains dan Bioteknologi

Fakulti Sains dan Teknologi

Universiti Kebangsaan Malaysia

43600 UKM Bangi, Selangor Darul Ehsan

Malaysia

*Pengarang untuk surat-menyurat; email: mahanem@ukm. edu.my

Diserahkan: 21 September 2017

Diterima : 8 Februari 2018 